\title{
Focus group and teaching-learning process in nursing: a systematic review of the literature
}

\section{Focus group e processo ensino-aprendizagem em enfermagem: uma revisão sistemática da literatura}

\author{
João José Rolo Longo ${ }^{1}$ Maria João Soares Rodrigues de Sousa Fernandes ${ }^{1,2}$ \\ ${ }^{1}$ Escola Superior de Saúde Ribeiro Sanches - ERISA, Rua do Telhal aos Olivais, nº8-8 ${ }^{\text {a }}$ 1900-693Lisboa, Portugal \\ ${ }^{2}$ CBIOS - Centro de Investigação em Ciências e Tecnologias da Saúde, Grupo Lusófona, Campo Grande, 376, 1749 - 024 \\ Lisboa \\ Email: maria.fernandes@erisa.pt
}

\begin{abstract}
Focus-group is strongly associated with qualitative approaches, revealing an extraordinary usefulness in research due to their heuristic qualities. This systematic literature review allows assessment of the state-of-the-art regarding the application of focus group, and the results of these focus group studies, particularly in the context of nursing education.

With an aim to analyse the utilization of focus group in the teaching-learning process in nursing, the following goals were set: to present the focus group as a method and technique of data collection; to identify advantages and limitations of its use in research as in the nursing teaching-learning processes. A systematic review of the literature was developed according to the PI(C)OD (Participants, Interventions, Comparisons, Outcomes, Design of the study) analysis protocol.

From 598 available articles, twelve meeting the eligibility criteria were selected and analyzed. We found that in qualitative studies, the focus group is presented as a useful method and technique to look deeper into human phenomena, especially those related to the learning process and its principle players. Results corroborate the information provided by the specialized literature, e.g., the focus group technique/method is useful when the intention is to assess experiences, perceptions, opinions, beliefs, values and attitudes, as is the case within many facets of the nursing teaching process.
\end{abstract}

Keywords: focus group, nursing, training in nursing.

\section{Resumo}

O focus group, fortemente associado a abordagens qualitativas, tem vindo a revelar-se nas últimas décadas uma notável ferramenta no âmbito da investigação em diferentes contextos educacionais dadas as suas qualidades heurísticas. A presente revisão sistemática da literatura permite-nos assim conhecer não só o estado da arte no que concerne à aplicação do focus group, como também as evidências produzidas pelo mesmo, designadamente, no âmbito da educação em enfermagem.

Tendo como alvo analisar a utilização do focus group na obtenção de dados referentes ao processo de ensino-aprendizagem no âmbito da formação em enfermagem, definiram-se os seguintes objetivos: apresentar o focus group como método e técnica de recolha de dados; identificar vantagens e limitações da sua utilização na investigação do processo de ensino-aprendizagem na enfermagem e respetivos atores.

Para atingir tais propósitos, foi realizada uma revisão sistemática da literatura segundo o protocolo de análise PI(C)OD (Participantes, Intervenções, Comparações, Outcomes, Desenho do estudo).

Dos 598 artigos disponíveis, foram selecionados e analisados 12 por cumprirem os critérios de elegibilidade. Verificámos que, em estudos de natureza qualitativa, o focus group apresenta-se como método e técnica útil para aprofundar os fenómenos do humano designadamente os relacionados com o processo de ensino-aprendizagem e seus atores. Os resultados vêm corroborar a informação disponibilizada pela literatura da especialidade, isto é, que o método/técnica focus group é facilitador quando se pretende aceder a experiências, percepções, opiniões, crenças, valores e atitudes, especificamente no processo de ensinoaprendizagem em enfermagem e seus atores.

Palavras-chave: focus group, enfermagem, formação em enfermagem 


\section{Introduction}

Research aims to produce knowledge. It is a methodical search for something, per se providing clarification on a particular subject of interest or concern to us. Thus, scientific research is a "study on a subject" [1].

The construction of knowledge in the area of education is a general concern of teaching. This is particularly true in nursing, where training meets a set of specific and complex challenges to achieve a professional performance that ultimately aims to care for citizens.

In this context, research has sought to make clear how teachers interact with students in order to join efforts and find ways to facilitate learning. The definition of learning objectives, teaching strategies and evaluation systems, are all considered, reflected and planned. Even the evaluation mechanisms created and applied in training practice are subject to constant changes in order to better verify and validate the efficacy, efficiency and effectiveness of implemented training processes. But the dissatisfaction continues and a constant search for an "ideal" means to better train competent nurses to satisfy, by their care, the demands of the target population and employers still remains.

Different tools for data collection are responsible for results and findings, and consequently for the production of knowledge in general and, particularly, in nursing as a discipline or a profession. The focus group has emerged since the mid-twentieth century as a method and a technique with increasing usefulness in the social sciences $[2,3,4]$, being extended to nursing since the 1990 's $[5,6]$. As a data collection tool, the focus group might provide an in-depth understanding of the individual's experiences in different contexts and settings [2]. In recent decades, numerous articles have been published resulting from investigations in which part or all of the information was collected by focus group. Nursing professionals, teachers and researchers are also increasingly turning to the focus group to investigate problems related with the intrinsic development of the teaching-learning process phenomena. The main objective of the present study arises from this context, intending to identify advantages and limitations of the application of focus group to the teaching and learning process in nursing and its principle players.

\section{Material and Methods}

A systematic review of the literature consists in appropriating the best evidence available at a given time

\section{Introdução}

A investigação tem como fim produzir conhecimento. Ela constitui per se a procura metódica de algo, proporcionando a clarificação de uma determinada temática que nos inquieta. Deste modo, a investigação científica será um "estudo sobre um tema" [1].

A construção do conhecimento na área da educação é uma preocupação da docência em geral. Na enfermagem, em concreto, a formação reúne um conjunto de desafios específicos e complexos quando aludimos a necessidade e exigência de formar profissionais cujo desenvolvimento de competências visa, na essência, o cuidado ao cidadão.

Neste contexto, a investigação tem procurado tornar clara a forma como docentes interagem com discentes de molde a conjuntamente, encontrarem caminhos facilitadores da aprendizagem. Desde a definição de objetivos de aprendizagem, estabelecimento de estratégias pedagógicas, ao sistema de avaliação, tudo é pensado, refletido e planeado. Os próprios mecanismos avaliativos criados e aplicados na prática formativa são alvo de constantes modificações no sentido de melhor se verificarem e validarem eficácia, eficiência e efetividade dos processos formativos implementados. Mas a inquietude permanece e continuamos numa procura constante da forma "ideal" de melhor se formar enfermeiros competentes para responder às solicitações da população alvo dos seus cuidados, empregadores e tutela.

Diferentes instrumentos para recolha de dados têm surgido responsáveis pela obtenção de resultados e achados, e consequentemente pela produção do conhecimento em geral e, particularmente em enfermagem quer como disciplina, quer como profissão. O focus group emerge assim, desde meados do século XX, como um método e uma técnica com crescente utilização nas ciências sociais ${ }^{[2,3,4]}$, estendendo-se à enfermagem a partir da década de $90^{[5,6]}$. Enquanto ferramenta de recolha de dados, pode fornecer uma compreensão em profundidade das experiências vividas pelas pessoas em determinados contextos e diferentes settings ${ }^{[2]}$. Nas últimas décadas, são inúmeros os artigos publicados resultantes de investigações, onde parte ou a totalidade da informação é recolhida através de focus group. Também, enfermeiros, professores e investigadores recorrem cada vez mais ao focus group para investigar as problemáticas relacionadas com os fenómenos intrínsecos ao desenvolvimento do processo de ensinoaprendizagem. Neste âmbito, surge o principal objetivo do presente estudo: identificar vantagens e limitações da utilização de focus groups na investigação do processo de ensino-aprendizagem na enfermagem e respetivos atores.

\section{Material e Métodos}

Uma revisão sistemática da literatura consiste na apropriação das melhores evidências disponíveis num 
interval and, through a methodical and critical appreciation, generating useful information and promoting evidence-based decision $[7,8]$. The present study was scientifically guided by the PI[C]OD method [9], whose components are shown in Table 1. determinado intervalo de tempo, através de uma apreciação, metódica e crítica, geradora de informação útil, possibilitadora da tomada de decisão baseada na evidência ${ }^{[7,8]}$. No presente estudo, a mesma foi norteada cientificamente pelo método $\mathrm{PI}[\mathrm{C}] \mathrm{OD}^{[9]}$ cujas componentes são explicitadas no Tabela 1.

Table 1/Tabela 1 - Research protocol

Protocolo de investigação

\begin{tabular}{|c|c|c|c|c|}
\hline $\mathbf{P}$ & $\begin{array}{l}\text { Participants } \\
\text { Participantes }\end{array}$ & $\begin{array}{l}\text { Who was studied? } \\
\text { Quem foi estudado? }\end{array}$ & $\begin{array}{l}\text { Nurse teachers and/or tutors and } \\
\text { students in clinical settings } \\
\text { Professores e/ou orientadores em } \\
\text { contexto clínico e/ou estudantes }\end{array}$ & \multirow{5}{*}{$\begin{array}{c}\text { Focus group; } \\
\text { Nursing. } \\
\text { Teaching } \\
\text { learning process } \\
\text { Palavras-chave: }\end{array}$} \\
\hline I & $\begin{array}{l}\text { Intervenções } \\
\text { Intervenções }\end{array}$ & $\begin{array}{l}\text { What was done? } \\
\text { O que foi feito? }\end{array}$ & $\begin{array}{l}\text { Using the focus group } \\
\text { Utilização do focus group }\end{array}$ & \\
\hline (C) & $\begin{array}{l}\text { Comparison } \\
\text { Comparações }\end{array}$ & $\begin{array}{l}\text { May or may not exist } \\
\text { Podem existir ou não }\end{array}$ & $\begin{array}{l}\text { Not exist } \\
\text { Não existem }\end{array}$ & \\
\hline O & Outcomes & $\begin{array}{l}\text { Outcomes/effects or } \\
\text { consequences } \\
\text { Resultados/efeitos ou } \\
\text { consequências }\end{array}$ & $\begin{array}{l}\text { Elements, factors, strategies } \\
\text { Elementos, fatores, estratégias }\end{array}$ & \\
\hline D & $\begin{array}{l}\text { Study design } \\
\text { Desenho do } \\
\text { estudo }\end{array}$ & $\begin{array}{l}\text { How evidence was collected? } \\
\text { Como é que a evidência foi } \\
\text { recolhida? }\end{array}$ & $\begin{array}{l}\text { Qualitative nature } \\
\text { Case study and ethnographic } \\
\text { Content analysis } \\
\text { Natureza qualitativa } \\
\text { Estudo de caso e etnográfico } \\
\text { Análise de conteúdo }\end{array}$ & \\
\hline
\end{tabular}

The research question was to know the extent to which the use of focus group (I) as a methodological option (D) provides details about the teaching-learning process in nursing $(\mathrm{O})$ and about its principle players, both teachers and/or tutors in the clinical and/or educational settings $(\mathrm{P})$.

A survey of publications available in full text, published between 2002 - 2012, in EBSCO (CINAHL Plus with Full Text, MEDLINE with Full Text, Database of Abstracts of Reviews of Effects, Cochrane Central Register of Controlled Trials, Cochrane Database of Systematic Reviews, Cochrane Methodology Register, Library, Information Science \& Technology Abstracts, Nursing \& Allied Health Collection: Comprehensive, MedicLatina, Health Technology Assessments, Academic Search Complete, NHS Economic Evaluation Database, Regional Business News, ERIC, Business Source Complete), was performed July 29th, 2012. This process was repeated on May 10th, 2013, applying
Partimos assim da questão de investigação: em que medida a utilização do focus group (I), como opção metodológica (D), permite obter dados sobre o processo de ensino-aprendizagem em enfermagem (O) e seus atores: professores e/ou orientadores em contexto clínico e/ou estudantes $(\mathrm{P})$ ?

Foi efetuada uma pesquisa dos artigos disponíveis em texto integral na EBSCO (CINAHL Plus with Full Text, MEDLINE with Full Text, Database of Abstracts of Reviews of Effects, Cochrane Central Register of Controlled Trials, Cochrane Database of Systematic Reviews, Cochrane Methodology Register, Library, Information Science \& Technology Abstracts, Nursing \& Allied Health Collection: Comprehensive, MedicLatina, Health Technology Assessments, Academic Search Complete, NHS Economic Evaluation Database, Regional Business News, ERIC, Business Source Complete) em 29 de julho 2012, publicados entre 2002 e 2012. Este processo foi repetido em 10 de maio de 2013, utilizando o intervalo de 2003 a 2013, com os 
the same search criteria and keywords - focus group, nursing and training in nursing - checking for overlap in articles available within the 2003 - 2013 interval. Some authors [9] consider that systematic literature reviews should focus on publications of the last five years. Nevertheless, we decided to search for the evidence of the last ten years.

From the available 598 papers, 14 were selected by the application of eligibility criteria (Table 2). Refining this search by full and detailed reading of selected papers lead us to eliminate two of these items which lacked methodological specification, such that the study comprised a total of twelve papers. mesmos critérios de busca e palavras-chave: focus group, nursing e training in nursing, verificando-se sobreposição nos artigos disponíveis. Apesar de alguns autores ${ }^{[9]}$ preconizarem que as revisões sistemáticas de literatura devam considerar as publicações dos últimos cinco anos, considerámos mais consistente o recurso à evidência dos últimos 10 anos.

Mediante os critérios de elegibilidade (Tabela 2), dos 598 artigos disponíveis, foram selecionados 14. Refinámos a pesquisa procedendo à leitura integral e detalhada dos artigos selecionados. Por ausência da explicitação metodológica não foram considerados dois destes artigos, pelo que, o estudo passou a compreender um total de 12 .

Table II/ Tabela II - Elegibility criteria of papers/studies

Critérios de elegibilidade dos artigos/estudos

\begin{tabular}{|l|l|l|}
\hline \multicolumn{1}{|c|}{$\begin{array}{c}\text { Elegibility criteria / } \\
\text { Critérios elegibilidade }\end{array}$} & \multicolumn{1}{c|}{$\begin{array}{c}\text { Inclusion criteria/ } \\
\text { Critérios de inclusão }\end{array}$} & \multicolumn{1}{c|}{$\begin{array}{c}\text { Exclusion criteria/ } \\
\text { Critérios de exclusão }\end{array}$} \\
\hline Participants & $\begin{array}{l}\text { Teachers, tutors in clinical } \\
\text { settings and students } \\
\text { Professores, orientadores em } \\
\text { contexto clínico e estudantes }\end{array}$ & - \\
\hline Opções metodológicas & $\begin{array}{l}\text { Using the Focus group } \\
\text { Utilização Focus group }\end{array}$ & $\begin{array}{l}\text { Absence of explicit methodology } \\
\text { Ausência de } \\
\text { metodológica }\end{array}$ \\
\hline Language & $\begin{array}{l}\text { Published papers in: English, } \\
\text { French, Spanish, Italian or } \\
\text { Portuguese } \\
\text { Idioma }\end{array}$ & $\begin{array}{l}\text { Artigos publicados em língua: } \\
\text { inglesa, francesa, espanhola, } \\
\text { italiana ou portuguesa }\end{array}$ \\
\hline
\end{tabular}

To evaluate the levels of evidence, we used the criteria suggested by Guyatt and Rennie [9]:

Level I - systematic reviews;

Level II - an experimental study;

Level III - quasi-experimental studies;

Level IV - no experimental studies;

Level V - report of program evaluation/literature reviews;

Level VI - authorities' opinion/consensus panels.

The final list of items to include in a systematic review of the literature is presented in Table 3. Diversified authors were only found in 2002, 2003, 2006, 2007 and 2008 publications. From these, one-half appeared in the Journal of Advanced Nursing. Studies were conducted in countries such as the UK, Australia, USA, Sweden
Para avaliarmos os níveis de evidência utilizámos os critérios sugeridos por Guyatt e Rennie ${ }^{[9]}$ :

Nível I - revisões sistemáticas;

Nível II - Estudo experimental;

Nível III - Estudos quase experimentais;

Nível IV - Estudos não experimentais;

Nível V - Relatório de avaliação de programa/revisões de literatura;

Nível VI - Opiniões de autoridades/painéis de consenso.

Obtivemos assim a listagem definitiva dos artigos a incluir na revisão sistemática da literatura, que apresentamos no Tabela 3. De autores diversificados, constatamos que só obtivemos publicações de 2002, 2003, 2006, 2007 e 2008. Destas, metade surgem no Journal 
and New Zealand. The absence of national studies on this matter was confirmed. of Advanced Nursing. São estudos desenvolvidos em países como o Reino Unido; Austrália; EUA; Suécia e Nova Zelândia. Verificamos a ausência de estudos nacionais sobre a temática em análise.

Table III/ Tabela III - Considered studies in the systematic review of the literature Estudos considerados na revisão sistemática da literatura

\begin{tabular}{|c|c|c|c|c|}
\hline $\begin{array}{c}\text { Code/Paper/Title/ } \\
\text { Código/Artigo/Título }\end{array}$ & $\begin{array}{l}\text { Author/ } \\
\text { Autor }\end{array}$ & $\begin{array}{c}\text { Publication/Year/Cou } \\
\text { ntry/ } \\
\text { Publicação/Ano/País }\end{array}$ & $\begin{array}{l}\text { Participants/ } \\
\text { Participantes }\end{array}$ & $\begin{array}{c}\text { Study design/ } \\
\text { Desenho do estudo }\end{array}$ \\
\hline $\begin{array}{l}\text { 1. Developing nursing and } \\
\text { midwifery research capacity } \\
\text { in a university department: } \\
\text { case study. }\end{array}$ & $\begin{array}{l}\text { Green B, } \\
\text { Segrott J, } \\
\text { Hewitt J. }\end{array}$ & $\begin{array}{l}\text { Journal of Advanced } \\
\text { Nursing. 56(3), 302-- } \\
313 \text {. } \\
\text { 2006/USA }\end{array}$ & $\begin{array}{l}\text { Nurse teacher } \\
\text { Professor de } \\
\text { enfermagem } \\
\quad(n=34)\end{array}$ & $\begin{array}{l}\text { Qualitative study } \\
\text { Case Study } \\
\text { Estudo qualitative } \\
\text { Estudo de Caso }\end{array}$ \\
\hline $\begin{array}{l}\text { 3. Learning Together:use of } \\
\text { simulated patients with } \\
\text { nursing and medical students } \\
\text { for breaking bad news. }\end{array}$ & $\begin{array}{l}\text { Wakefield A, } \\
\text { Cooke S, } \\
\text { Boggis C. }\end{array}$ & $\begin{array}{l}\text { International Journal of } \\
\text { Palliative Nursing; Vol } \\
9, \mathrm{n}^{\circ} 1,32-38 \text {. } \\
\text { 2003/UK }\end{array}$ & $\begin{array}{l}\text { Nurse and } \\
\text { medical students } \\
\text { Estudantes de } \\
\text { enfermagem e } \\
\text { de medicina } \\
(n=34)\end{array}$ & $\begin{array}{l}\text { Qualitative study } \\
\text { Estudo qualitativo }\end{array}$ \\
\hline $\begin{array}{l}\text { 4. Nursing student } \\
\text { perceptions of community in } \\
\text { online learning. }\end{array}$ & $\begin{array}{l}\text { Gallagher- } \\
\text { Lepak S, } \\
\text { Reilly J, } \\
\text { Killion CM. }\end{array}$ & $\begin{array}{l}\text { Contemporary } \\
\text { Nurse32(1-2),133-146. } \\
\text { 2009/USA }\end{array}$ & $\begin{array}{l}\text { Nurse students } \\
\text { Estudantes de } \\
\text { enfermagem } \\
(n=18)\end{array}$ & $\begin{array}{l}\text { Qualitative study } \\
\text { Estudo qualitativo }\end{array}$ \\
\hline $\begin{array}{l}\text { 5. Online learning: } \\
\text { enhancing nurse education? }\end{array}$ & Kenny A. & $\begin{array}{l}\text { Journal of Advanced } \\
\text { Nursing; 38(2), 127- } \\
135 \text {. } \\
2002 \text { /Australia }\end{array}$ & $\begin{array}{l}\text { Nurse students } \\
\text { Estudantes de } \\
\text { enfermagem } \\
(n=21)\end{array}$ & $\begin{array}{l}\text { Qualitative study } \\
\text { Estudo qualitativo }\end{array}$ \\
\hline $\begin{array}{l}\text { 6. Managing capacity issues } \\
\text { in clinical placements for } \\
\text { pre-registration Nurses }\end{array}$ & $\begin{array}{l}\text { Murray S, } \\
\text { Williamson } \\
\text { GR. }\end{array}$ & $\begin{array}{l}\text { Journal of Clinical } \\
\text { Nursing, 18, 3146- } \\
3154 \text {. } \\
2009 / \text { UK }\end{array}$ & $\begin{array}{l}\text { Nurse tutors } \\
\text { Tutores de } \\
\text { enfermagem } \\
(n=29)\end{array}$ & $\begin{array}{l}\text { Qualitative study } \\
\text { Estudo qualitativo }\end{array}$ \\
\hline $\begin{array}{l}\text { 7. Nurse supervisors' actions } \\
\text { in relation to their decision- } \\
\text { making } \\
\text { style and ethical approach to } \\
\text { clinical supervision }\end{array}$ & $\begin{array}{l}\text { Berggren I, } \\
\text { Severinsson E. }\end{array}$ & $\begin{array}{l}\text { Journal of Advanced } \\
\text { Nursing, 41(6), 615- } \\
622 \text {. } \\
2003 / \text { Sweden }\end{array}$ & $\begin{array}{l}\text { Nurse } \\
\text { supervisors } \\
\text { Supervisores de } \\
\text { enfermagem } \\
(\mathrm{n}=4)\end{array}$ & $\begin{array}{l}\text { Qualitative study } \\
\text { Estudo qualitativo }\end{array}$ \\
\hline $\begin{array}{l}\text { 8. Stress and eustress in } \\
\text { nursing students }\end{array}$ & $\begin{array}{l}\text { Gibbons C, } \\
\text { Dempstar M, } \\
\text { Moutray M. }\end{array}$ & $\begin{array}{l}\text { Journal of Advanced } \\
\text { Nursing - Journal } \\
\text { compilation, 208-290. } \\
\text { 2007/UK }\end{array}$ & $\begin{array}{l}\text { Nurse students } \\
\text { Estudantes de } \\
\text { enfermagem } \\
(n=16)\end{array}$ & $\begin{array}{l}\text { Qualitative study } \\
\text { Estudo qualitativo }\end{array}$ \\
\hline $\begin{array}{l}\text { 9. The highs and lows of } \\
\text { learning to be a children's } \\
\text { nurse }\end{array}$ & $\begin{array}{l}\text { Glasper A, } \\
\text { Richardson J, } \\
\text { Whiting M. }\end{array}$ & $\begin{array}{l}\text { Paediatric nursing July } \\
\text { vol } 18 \mathrm{n}^{\circ} 6,22-26 \text {. } \\
2006 / \mathrm{UK}\end{array}$ & $\begin{array}{l}\text { Nurse students } \\
\text { Estudantes de } \\
\text { enfermagem } \\
\quad(n=34)\end{array}$ & $\begin{array}{l}\text { Qualitative study } \\
\text { Estudo qualitativo }\end{array}$ \\
\hline $\begin{array}{l}\text { 10. The Introduction of } \\
\text { Reflective Practice to } \\
\text { Japanese Nurses. }\end{array}$ & $\begin{array}{l}\text { Stochhausen } \\
\text { L, } \\
\text { Kavwashima } \\
\text { A. }\end{array}$ & $\begin{array}{l}\text { Reflective Practice, } \\
\text { Vol. 3, No. 1, 117-129. } \\
\text { 2002/UK }\end{array}$ & $\begin{array}{l}\text { Nurse students } \\
\text { Estudantes de } \\
\text { enfermagem } \\
\quad(n=27)\end{array}$ & $\begin{array}{l}\text { Ethnographic } \\
\text { Study } \\
\text { Estudo etnográfico }\end{array}$ \\
\hline $\begin{array}{l}\text { 11. The relationship between } \\
\text { student nurse and nurse } \\
\text { clinician: impact on student } \\
\text { learning }\end{array}$ & $\begin{array}{l}\text { Vallant S, } \\
\text { Neville S. }\end{array}$ & $\begin{array}{l}\text { Nursing Praxis in New } \\
\text { Zealand Vol. } 22 \mathrm{n}^{\circ} 3 \text {, } \\
23-33 \text {. } \\
\text { 2006/New Zealand }\end{array}$ & $\begin{array}{l}\text { Nurse students } \\
\text { Estudantes de } \\
\text { enfermagem } \\
\quad(n=11)\end{array}$ & $\begin{array}{l}\text { Qualitative study } \\
\text { Estudo qualitativo }\end{array}$ \\
\hline $\begin{array}{l}\text { 12. Time to precept: } \\
\text { supportive and limiting } \\
\text { conditions for precepting } \\
\text { nurses }\end{array}$ & $\begin{array}{l}\text { Carlson E, } \\
\text { Pilhammar E, } \\
\text { Wann- } \\
\text { Hansson C. }\end{array}$ & $\begin{array}{l}\text { Journal of Advanced } \\
\text { Nursing - Journal } \\
\text { compilation, 432-441. } \\
\text { 2009/Sweden }\end{array}$ & $\begin{array}{l}\text { Nurse preceptors } \\
\text { Percetores de } \\
\text { enfermagem } \\
(\mathrm{n}=16)\end{array}$ & $\begin{array}{l}\text { Qualitative study } \\
\text { Estudo qualitativo }\end{array}$ \\
\hline $\begin{array}{l}\text { 14. Nursing students' } \\
\text { perceptions of learning in } \\
\text { the clinical setting of the } \\
\text { Dedicated Education Unit }\end{array}$ & $\begin{array}{l}\text { Ranse K, } \\
\text { Grealish L. }\end{array}$ & $\begin{array}{l}\text { Journal of Advanced } \\
\text { Nursing - Journal } \\
\text { compilation, 171-179. } \\
\text { 2007/Australia }\end{array}$ & $\begin{array}{l}\text { Nurse students } \\
\text { Estudantes de } \\
\text { enfermagem } \\
\quad(n=25)\end{array}$ & $\begin{array}{l}\text { Qualitative study } \\
\text { (exploratory) } \\
\text { Estudo qualitativo } \\
\text { (exploratório) }\end{array}$ \\
\hline
\end{tabular}




\section{Results}

From these analysis we find that the different groups of key informants include samples ranging from 4 to 34 elements. We also note that in most studies (8), participants are students, while in the remaining four the participants are teachers and/or clinical teaching tutors. Only one of these last studies specifically addresses teachers.

It is noteworthy to register that in most studies, the focus group is used as the main method/technique of data collection.

Regarding meeting preparation, researchers begin by describing how participants are distributed, despite the group's constitutions, it is not differentiated in most of the papers. The number of groups is variable (between one and seven), as is the number of elements per group (between three and seven).

Regarding the development of the focus group sessions, the majority of researchers choose to start the debate by a semi-structured interview with open questions. Only two situations reported requiring experienced research and external moderators.

Transversely, we found out that only five of the studies mentioned session duration, ranging from 30 minutes to 90 minutes. The information session was recorded by audio in all but one paper [9].

Concerning results, there is evidence that this focus group technique/method is useful and facilitates data collection in the teaching-learning process of the nursing graduate studies, namely: (i) the importance of investigative training for the faculty educators; (ii) the advantages of using role-playing in the development of professional and inter-user interaction; (iii) the benefits resulting from the application of information and communication technologies (ICT) in the teaching-learning process; (iv) the improvement of clinical supervision resulting from better coordination between academic and work contexts; (v) the clinical supervisor training needs; (vi) the importance of pedagogy in the clinical context and the characteristics of the supervisor in the academic success of the student; (vii) the importance of reflective practice in postgraduate training; (viii) the influence of clinical settings in the formative processes. Only two studies referred to the qualitative research design chosen - ethnographic and case study. Regarding data collection, we have confirmed that the focus group is used as a principal technique in eight of the studies, while in those remaining it is used as a complementary technique to the semi-structured interview, to the questionnaire, and to the participant observation technique. In this latter study, it also served as validation of the result's process.

\section{Resultados}

Da presente análise, constatamos que os diversos grupos de informantes-chave são constituídos por "amostras" que vão desde os quatro aos 34 elementos. Verificamos também que, na maioria dos estudos (oito), os participantes são estudantes e os restantes (quatro) são professores e/ou orientadores em ensino clínico. Destes últimos, apenas um estudo versa especificamente os professores.

De particular interesse destacamos, no âmbito das intervenções, que na generalidade dos estudos, o focus group é utilizado como principal método/técnica de recolha de dados.

No que toca à preparação das sessões, emerge que os investigadores começam por relatar o modo como distribuem os participantes, apesar de não ser discriminada a constituição dos grupos em todos os artigos. O número de grupos utilizado é variável: entre um e sete, bem como o número de elementos por grupo: entre três a sete.

No que concerne ao desenvolvimento das sessões de focus group, os investigadores optam maioritariamente por iniciar o debate com a colocação de questões abertas na linha de entrevista semi-estruturada. Só em duas situações, são requisitados moderadores experientes e externos àinvestigação.

Transversalmente, verificamos que apenas em cinco dos estudos é mencionada a duração das sessões, que varia entre 30 minutos e 90 minutos. A informação é sempre registada por audio-gravação exceto em um dos artigos ${ }^{[9]}$.

Ao nível dos resultados, a técnica/método de focus group evidencia-se como útil e facilitadora na obtenção de dados relativos ao processo de ensino-aprendizagem na formação em enfermagem, designadamente no que se refere a: (i) importância do treino investigativo do corpo docente; (ii) vantagens da utilização do cliente simulado no desenvolvimento da interação profissionalutente e interprofissional; (iii) benefícios da utilização das tecnologias de informação e comunicação (TIC) no processo de ensino-aprendizagem; (iv) melhoria da supervisão clínica por via de uma melhor articulação ente academia e contextos de trabalho; (v) necessidades de formação do supervisor clínico; (vi) relevância da relação pedagógica em contexto clínico e das caraterísticas do supervisor no sucesso académico do estudante; (vii) importância da prática reflexiva na formação pósgraduada; (viii) influência dos settings clínicos nos processos formativos.

Apenas dois estudos enunciam o desenho de investigação qualitativa selecionado: etnográfico e estudo de caso. Relativamente à recolha de dados verificamos que o focus group é utilizado como técnica principal 
Only seven studies referred to the data collection time elapsed, ranging from two weeks to four months.

Finally, all analyzed items were within the evidence level of IV [9].

\section{Discussion}

In order to answer the initial question - to what extent the use of focus group as a methodological option allows data on the of teaching and learning process of nursing and its principle players (teachers, clinical tutors and students) to be obtained - it is important to note the absence of national publications, which are essentially limited to the Anglo-Saxon countries.

Researchers selected the focus group as a method or as a technique for gathering information based on the qualitative paradigm. As a method, it was selected because its procedures allowed researchers to reach the previously established objectives with the designed resources. As a technique, it was selected because they used the tool according to the applicability of their underlying standards. The focus group method is an appropriate way to obtain the desired data. The focus group technique is the art of walking through perceptions, opinions, desires, beliefs, values and within collective interaction attitudes, until we find the data we seek $[2,3,4,10,11,12]$. It is the interaction that validates the method, because what participants say is confirmed, reinforced or contradicted within the discussion group $[5,13]$. Results on each issue do not emerge from each individual but rather from discussion within the different elements of the group $[13,14,15]$. The issue is rejected, confirmed and/or reinforced by creating new knowledge [16, 17, 18, 19].

The focus group can be used at any stage of research $[12,13,19,20,21]$. In preliminary studies or pilot stages, it can be used to generate hypotheses and explore a phenomenon $[14,16,17,19]$. In late or final stages it can be applied to assess impacts and to project development research [14, 17, 19]. It is also used in mixed studies for the acquisition of particular indicators and for the construction of questionnaires as tools to produce information $[18,19]$. For this paper's analysis we confirmed the use of the focus group per se or included in more complex methodological approaches (ethnography and case study) and/or combined with other techniques (questionnaires, semi-structured interviews and em oito dos estudos e nos restantes apresenta-se como técnica complementar à entrevista semi-estruturada, ao questionário e à observação participante. Neste último serviu como processo de validação de resultados.

Somente sete estudos se referem ao tempo em que decorreu a recolha de dados, oscilando entre duas semanas a quatro meses.

Por último, todos os artigos analisados situam-se no nível de evidência IV ${ }^{[9]}$.

\section{Discussão}

$\mathrm{Na}$ procura de responder à questão inicial - em que medida a utilização do focus group, como opção metodológica, permite obter dados sobre o processo de ensino-aprendizagem em enfermagem e seus atores: professores, orientadores em contexto clínico e estudantes? Importa constatar a inexistência de publicações nacionais, limitando-se as mesmas essencialmente a países anglo-saxónicos.

Tendo por base o paradigma qualitativo, os investigadores selecionaram o focus group ora como método, ora como técnica para a recolha de informação. Método, porque através dos seus procedimentos os investigadores atingiram o fim que preestabeleceram, os objetivos que definiram, com os recursos que estipularam e como os conceberam. Técnica, porque utilizaram a ferramenta mediante as suas normas subjacentes de aplicabilidade. O método focus group é o caminho para se obter os dados pretendidos. A técnica focus group é a arte de caminhar pelas perceções, opiniões, desejos, crenças, valores e atitudes nas interações coletivas, até encontrarmos os dados que procuramos ${ }^{[2,3,4,10,11,12]}$. É a interação que confere validade ao método, porque o que os participantes dizem é confirmado, reforçado ou contrariado no seio do grupo de discussão ${ }^{[5,13]}$. Os resultados não são obtidos de uma forma individualizada, mas sim, do que emerge da discussão entre os diferentes elementos do grupo sobre o assunto ${ }^{[13,14,15]}$. Este é rejeitado, confirmado e/ou reforçado criando novo conhecimento ${ }^{[16,17,18,19]}$.

O focus group pode ser usado em qualquer etapa da investigação ${ }^{[12,13,19,20,21]}$. Em fases preliminares ou em estudos pilotos, pode ser usado para gerar hipóteses e explorar um fenómeno ${ }^{[14,16,17,19]}$. Em fases finais ou definitivas, pode ser aplicado para avaliações do impacto e desenvolvimento do projeto de investigação ${ }^{[14,17,19]}$. É usado também em estudos mistos nomeadamente na aquisição de indicadores para a construção de questionários como instrumentos de produção de informação ${ }^{[18,19]}$. Dos artigos analisados, verificamos o uso do focus group de forma isolada, ou inserido em abordagens metodológicas mais complexas (estudo 
participant observation) either for initial data collection or for validation of results/findings.

Regarding the organization and implementation of the focus group sessions, most of researchers complied with the recommendations published in the literature $[10,13,16,21,22]$. Participants were selected based on the contribution of knowledge they could offer to the research topic. We confirmed the variation in the number of groups (one to seven) or in its constitution (three to seven elements). Participants became more confident with the groups homogeneity while heterogeneity facilitated raising other different points of view, reconciling uniformity to diversity. However, from Article 10 we find that culture, gender, age and hierarchy are aspects that might influence the session's dynamics, as emphasized by several authors $[10,13,16]$.

The management and moderation of focus group are explicit regarding how the debate is triggered (placement of open questions) as by the moderation process (by a semi-structured interview script). For some authors $[3,16]$ the success of the focus group depends on the competence of the moderator and the questions asked. The moderator should possess certain characteristics, such as listening skills, calm, empathy, sensitivity and competence, to concentrate a large amount of data on that specific subject under study [20]. This may be the reason that, in two of the articles, researchers decided to use external moderators. As some authors argue [4], when the moderator is independent of the research team, it can better ensure the study subjects will not be influenced [4]. Some authors [16] also recommend an observer or assistant to take notes and/or ensure the operation; however, in these papers this recommendation was not considered.

The debate can be audio-recorded or video-recorded as well $[12,23]$. In all of the included papers, information registration took place by audio-recording.

Commonly, the duration of focus group sessions range from one to two hours $[4,10,23]$, although muchof the included research does not mention this information. However, from the existing information we noted a duration range from 30 minutes to 90 minutes. The time period over which the sessions occurred is also not often referred. From the seven included studies that provided this information, data collection took place mainly in one time interval with a duration range varying between two weeks to four months.

For data treatment and analysis, we have found some procedural uniformity in content analysis. This option enables a heuristic interpretation, facilitating the subject speech movements towards research, increasing the discovery potential of the underlying material collected by these focus group sessions [24, 25, 26, 27]. etnográfico e estudo de caso) e/ou em conjunto com outras técnicas (questionário, entrevista semi-estruturada e observação participante) quer para recolha inicial, quer para validação de resultados/achados.

Os investigadores cumpriram maioritariamente $\mathrm{o}$ recomendado na literatura da especialidade quanto à organização e implementação das sessões de focus group $^{[10,13,16,21,22]}$. Os participantes foram selecionados mediante o conhecimento que podiam oferecer ao tema de investigação. Verificamos a variação quer no número de grupos (um a sete), quer na sua constituição (três a sete elementos). A homogeneidade nos grupos tornou os participantes mais confiantes e a heterogeneidade facilitou a angariação de mais e diferentes pontos de vista, conciliando a uniformidade com a diversidade. Porém, no artigo 10, verificamos que cultura, género, idade e hierarquia são aspetos que podem influenciar a dinâmica das sessões tal como é sublinhado por diversos autores ${ }^{[10,13,16,]}$.

A condução/moderação dos focus groups é explícita, quanto à forma como é desencadeado o debate (colocação de questões abertas) bem como quanto ao processo de moderação (mediante guião de entrevista semi-estruturada). Para alguns autores ${ }^{[3,16]}$, o sucesso do focus group depende da competência do moderador e das perguntas formuladas. O moderador deverá ser detentor de características como: capacidade de escuta, calma, empatia, sensibilidade e competência para obter grande concentração de dados sobre o tema específico em estudo ${ }^{[20]}$. Talvez por isso, em dois dos artigos, os investigadores optaram por recorrer a moderadores externos, tal como alguns autores defendem ${ }^{[4]}$ : quando o moderador é independente da equipa de investigação poderá assegurar-se melhor a sua não influência nos assuntos em estudo ${ }^{[4]}$. Alguns autores ${ }^{[16]}$ sugerem ainda a existência de um observador ou assistente que tome notas e e/ou assegure o funcionamento dos meios técnicos. No entanto, nos artigos considerados, tal não se verifica.

O debate pode ser áudio-gravado ou também vídeogravado $^{[12,23]}$. Em todos os artigos, a forma de registo de informação é idêntica: a audio-gravação.

Comumente, as sessões de focus group têm uma duração compreendida entre uma a duas horas ${ }^{[4,10,23]}$. A generalidade das investigações é omissa relativamente a esta informação. Contudo, da existente, constamos uma duração que oscila entre 30 minutos e 90 minutos. Também nem sempre é declarado o timing em que ocorreram. Dos sete estudos em que esta informação é fornecida, a recolha de dados decorreu maioritariamente num só intervalo de tempo com uma duração que oscila entre duas semanas e quatro meses. Quanto ao tratamento e análise de dados, constatamos uniformidade no procedimento: análise de conteúdo. Esta opção viabiliza uma interpretação heurística facilitadora da passagem do discurso dos sujeitos ao sentido 
Regarding ethics, the informed consent and institutional clearance where the study took place are explicit in most of the studies. In fact, ethical aspects are crucial for research. Ensuring the rights, freedoms, and consent of participants and institutions should be ensured by the investigator. The informed written consent and neutrality and impartiality in data analysis are fundamental ethical issues to be considered [12, 28, 29].

The usefulness and limitations from using the focus group method / technique are not listed in the studied papers, although it is clear that these are accordingly applied as indicated in the available literature [3, 10, $12,14,15,17,18,19,20,22,23,30]$. As major advantages, we might point out (i) it allows to gather data from a wide range of varied highly valuable sources in a fast, low cost way; (ii) it promotes knowledge about individual's way of thinking and speaking on certain topics (and others not previously considered) and how to defend their points of view; (iii) it encourages participants to talk freely with each other, to question and comment on their own experiences, ideas, roles and criteria in a non-determined manner; (iv) it allows clarification of the answer to these questions, facilitating the meanings identification and their relationships, including the modification of ideas or even behaviors; (v) it provides the opportunity for participants to enter the discussion at anytime and anywhere in the online version. As major main limitations, we point out (i) the scheduling difficulty to gather all the required people, (ii) conditioning the group (or some of its elements) dynamics for cultural and/or social heterogeneity; (iii) training/experience of the moderator/researcher; (iv) the risk of the group being taken by a member, raising the possibility that the data obtained does not correspond to the group's idea but rather to a single participant; (v) shifting discussion to other topics ; (vi) being useless to generalize data.

\section{Conclusions}

This systematic review of the literature, conducted in accordance with the protocol analysis PI [C]OD, led to the conclusion that the focus group method/technique is useful when the objective is to collect a broad amount of data on the process of teaching-learning in nursing and its principle players: teachers/clinical tutors and students.

If the nature of the desired data determines the type of instrument to be used, this, in turn, determines the type da pesquisa, aumentando o potencial de descoberta da realidade subjacente ao material recolhido através das sessões de focus group $^{[24,25,26,27]}$.

No que concerne aos procedimentos éticos, é maioritariamente explicitada a obtenção do consentimento informado dos participantes e a autorização das organizações onde o estudo decorreu. Com efeito, os aspetos éticos são decisivos em investigação. A garantia dos direitos, liberdades e consentimento dos participantes e instituições deve ser assegurada pelo investigador. O consentimento informado sob a forma escrita e a neutralidade e imparcialidade na análise dos dados são questões éticas fundamentais a serem consideradas ${ }^{[12,28,29]}$.

Apesar de não serem enunciadas vantagens e limitações da utilização do método/técnica de focus group, da análise dos artigos considerados evidencia-se que estas vão de acordo com o apontado pela literatura disponível ${ }^{[3,10,12,14,15,17,18,19,20,22,23,30]}$. Enumeramos como principais vantagens (i) permite obter dados de um número alargado de pessoas num curto intervalo de tempo, a baixo custo, recolhendo um grande volume e riqueza de informação; (ii) promove o conhecimento de como as pessoas pensam e falam sobre determinados temas (e outros nunca pensados) e como defendem os seus pontos de vista; (iii) encoraja os participantes a falarem livremente entre si, a questionarem e comentarem as suas experiências, ideias, papéis e critérios, de forma não diretiva; (iv) possibilita a clarificação das respostas às questões formuladas, facilitando a identificação de significados e suas relações, inclusive a mudança de ideias e até de comportamentos; (v) oferece a oportunidade aos participantes de entrarem na discussão em qualquer altura e em qualquer lugar na versão on-line. Como principais limitações apontamos (i) a dificuldade em agendar e reunir a totalidade das pessoas pretendidas, por motivos logísticos; (ii) condicionamento da dinâmica de grupo (ou de alguns elementos) por heterogeneidade cultural e/ou social; (iii) treino/experiência do moderador/investigador; (iv) risco de domínio do grupo por um dos elementos ou possibilidade de os dados obtidos não corresponderem à ideia do grupo mas sim de um só participante; (v) desvio da discussão para outros temas; (vi) não serve para generalizar dados.

\section{Conclusões}

A revisão sistemática da literatura que agora se apresenta, orientada pelo protocolo de análise PI[C]OD, permite-nos concluir que o método/técnica focus group é de utilidade quando se pretende recolher um volume alargado de dados sobre o processo de ensino-aprendizagem em enfermagem e respetivos atores: professores/ orientadores em contexto clínico e estudantes.

Se a natureza dos dados que queremos obter determina o tipo de instrumento a utilizar, este, por sua vez, 
of information collected. The focus group is, in fact, presented as a method and a technique of choice when the researcher wants to rapidly access, in the collective interplay, the participants' representations on a particular subject.

It is still potentially advantageous to apply this method/ technique either independently or in addition to other data collection methods, thus evidencing its heuristic potential for understanding human phenomena. Main limitations of this approach involve scheduling logistics, moderation, and also those constraints resulting from the session dynamics. Considering all discussed advantages and limitations, it is obvious that the focus group should be carefully developed with attendance to all the epistemological and methodological principles. It is our intention, with the present paper, to contribute to a critical analysis and a thoughtful use of this particular methodological procedure for the teaching-learning process in nursing education.

\section{Conflict of Interests}

The authors declare that there are no financial and / or personal relations that could be viewed as a potential conflict of interests. condiciona o tipo de informação recolhida. O focus group apresenta-se de facto, como um método e uma técnica de eleição quando o investigador pretende aceder, na interação coletiva e de modo célere, às representações dos participantes sobre um determinado assunto. Emerge ainda como vantagem a possibilidade de aplicação deste método/técnica quer de forma isolada quer em complemento com outras modalidades de recolha de dados, evidenciando-se assim as suas potencialidades heurísticas para a compreensão dos fenómenos do humano.

Como principais limitações apontam-se os aspetos ligados à logística, à moderação, e ainda, aos constrangimentos decorrentes da própria dinâmica das sessões.

Mediante as vantagens e limitações apresentadas evidencia-se a necessidade de desenvolver o focus group de forma criteriosa, observando os princípios epistemológicos e metodológicos.

Pretendemos, com este artigo, contribuir para uma análise crítica e uma utilização ponderada deste procedimento metodológico designadamente no processo de ensino-aprendizagem na formação em enfermagem.

\section{Conflito de Interesses}

Os autores declaram que não existem relações financeiras ou pessoais que possam ser entendidas como potenciais conflitos de interesse. 


\section{References / Referências}

[1] Kernerman Portuguese Learners Dictionary, K. Dictionaries, 2008.

[2] Freeman T. 'Best practice' in focus group research: making sense of different views. Journal of Advanced Nursing, 56:5 (2006) 491-497.

[3] Halcomb E. Literature review: considerations in undertaking focus group research with culturally and linguistically diverse groups. Preview. Journal of Clinical Nursing, 16: 6 (Junho 2007), p. 1000-1011

[4] Hannes K., Vandersmissen, J., Blaeser, L., Peeters, G., Goedhuys, J., Aertgeerts, B. Barriers to evidence-based nursing: a focus group study. Journal of Advanced Nursing, 60:2 (Outubro 2007) p. 162-71

[5] Webb C, Kevern J. Focus groups as a research method: a critique of some aspects of their use in nursing research. Journal of Advanced Nursing, 33:6 (2001) 798-805.

[6] Gibson F, Bamford, O. Focus group interviews to examine the role and development of the clinical nurse specialist. Journal of Nursing Management, 9:6 (2001) 331-342.

[7] Pereira AL, Bachion MM. Atualidades em revisão sistemática de literatura, critérios de força e grau de recomendação de evidência. 2006; Rev. Gaúcha de Enfermagem, dez, 27(4),491-498.

[8] Sampaio RF, Mancini MC. Estudos de revisão sistemática: um guia para síntese criteriosa da evidência científica 2007; Revista brasileira de fisioterapia, São Carlos, janfev, v. 11, n' $1,83-89$.

[9] Guyatt GH, Rennie D. User's Guides to the medical literature: a manual for evidencebased clinical practice. Chicago: American Medical Association; 2002.
[10] Curtis E, Redmond R. Focus groups in nursing research. Nurse Researcher, 14:2; 2007, 25-37.

[11] Baribeau C. L'entretien de groupe : considérations théoriques et méthodologiques 2010; Recherches qualitatives, Vol. 29(1), 2010, pp. 28-49.

[12] Nunes AP. A utilização da técnica dos grupos focais na metodologia de investigação qualitativa; Revista de Investigação em Enfermagem, 2012; fev, 89-94.

[13] Krueger, RA. Focus Groups: A Practical Guide for Applied Research. London: Sage Publications; 1994.

[14] Björvell C. Improving documentation using a nursing model. Journal of Advanced Nursing, 43:4 2003; p.402-410.

[15] Happell B. Focus groups in nursing research: an appropriate method or the latest fad? Nurse Researcher, 14:2 2007; p. 18-24.

[16] Mansell I. The learning curve: the advantages and disadvantages in the use of focus groups as a method of data collection. Nurse Researcher, 11:4 2004; p. 79-88.

[17] Kenny A. Interaction in cyberspace: an online focus group. Journal of Advanced Nursing 49:4 2005; p. 414-22.

[18] Kitzinger B.. Developing Focus Group Research: Politics, Theory and Practice. London: Sage Publications; 1999.

[19] Ivanoff S, Hultberg J. Understanding the multiple realities of everyday life: Basic assumptions in focus-group methodology. Scandinavian Journal of Occupational Therapy. 13 2006; p. 125-132.

[20] Morgan D. Focus group as qualitative research $2^{\mathrm{a}}$ ed. Massachusetts: Sage; 1996.
[21] Flick U. Métodos Qualitativos na Investigação Científica: Lisboa: Monitor; 2005.

[22] Howatson-Jones L. Dilemmas of focus group recruitment and implementation: a pilot perspective. Nurse Researcher, 14:2 (2007), p. 7-17

[23] Verpeet E. , Casterle, B. , Arend, A. , Gastmans, C. Nurses' views on ethical codes: a focus group study. Journal of Advanced Nursing, 51:2 (2005)188-195.

[24] Bardin L. Análise de conteúdo. Lisboa: Edições 70; 2013.

[25] Vala J. Análise de conteúdo. In: Silva AS, Pinto MJ (Org). Metodologias das Ciências Sociais. $7^{\mathrm{a}}$ ed. , Porto: Porto Editora; 1986.

[26] Huberman M, Miles M. Analyse des données qualitative. Bruxelles: De Boeck; 1991

[27] Ghiglione R, Matalon B. O inquérito. Oeiras: Celta Editora; 1992.

[28] Denzin K, Lincoln Y. Introduction: entering the field of qualitative research. In: Denzin K, Lincoln Y. (Eds). Handbook of qualitative research. Netbury Park: Sage; 1994.

[29] Erikson E. The Life Cycle Completed. New York: Norton; 1998.

[30] Sapeta P, Lopes M. Cuidar em fim de vida: fatores que interferem no processo de interação enfermeiro-doente. Rev. Referência II ${ }^{\mathrm{a}}$ Série ${ }^{\circ} 4$ - junho; 2007. 